Open Access

\title{
E-literacy-adoption model and performance of women-owned SMEs in Southwestern Nigeria
}

\author{
Ojinga G. Omiunu(D)
}

\author{
Correspondence: \\ omiunuojingag@gmail.com \\ Africa Regional Centre for \\ Information Science, University of \\ Ibadan, P.O. Box 22133, No. 6 Benue \\ Road, U.I. Post Office, Ibadan, \\ Nigeria
}

\begin{abstract}
The study investigates the moderating effect of e-literacy and business information strategy on the relationship between ICT adoption and performance of womenowned SMEs in Southwestern Nigeria. The theories of information technology trilogy by (J Strateg Inf Syst 10:77-99, 2001) coupled with the ICT literacy of (MediaSmarts, Digital Literacy Funadamentals, Canada's Centre for Digital and Media Literacy MediaSmarts, 2017) which in this study is conceptualized as e-literacy were adapted, and five hypotheses were formulated towards proposing an e-literacy-adoption model for enhanced SMEs' performance. The study adopted the correlational survey research design and consists of women-owned SMEs in Southwestern, Nigeria. A multi-stage sampling was employed in the study, and a sample size of 240 womenowned SMEs was drawn. However, 236 were retrieved, giving a 94.4\% response rate. The questionnaire was used to obtain information, and the correlation analysis was used to analyze the data obtained. The result of the study revealed that e-literacy and business information strategy are significant to the adoption of ICT for effective performance among women-owned SMEs in Nigeria. The study recommends that governments and various NGOs committed to enhancing the growth and development of women-owned SMEs in Nigeria should provide necessary grants and sponsorship towards providing necessary ICT workshops and trainings that could enhance women-owned SMEs' e-literacy and skills and also the adoption of ICT towards a better performance.
\end{abstract}

Keywords: E-literacy-adoption model, Performance of women-owned SMEs, Women-owned SMEs in Nigeria

\section{Introduction}

The small and medium enterprises (SMEs)' sector plays a significant role in the economic growth and development of most nations, and this has made it to attract attention from scholars and stakeholders of development. It is thus given consideration in national planning and development. Studies such as Hashim (2000), Watson (2003), Jamil and Mohamed (2011), Hakimpoor et al. (2011), Kutllovci et al. (2012), Mahmood and Hanafi (2013), Fowler (2017), Ngage Media Services Pvt Ltd (2017), Organisation of Economic Co-operation and Development (OECD) (2017), and Ata (2018) have attested to the contributory role of SMEs to development which can cut across personal, family, society, and national development. Despite its significant role, studies

(c) The Author(s). 2019 Open Access This article is distributed under the terms of the Creative Commons Attribution 4.0 International License (http://creativecommons.org/licenses/by/4.0/), which permits unrestricted use, distribution, and reproduction in any medium, provided you give appropriate credit to the original author(s) and the source, provide a link to the Creative Commons license, and indicate if changes were made. 
have affirmed that performance of SMEs is low in developing countries such as Nigeria and this has made them not to be able to contribute their quota effectively to national development and also could not allow them to measure up to those in developed countries (Onugu 2005; Organisation of Economic Co-operation and Development (OECD) 2017). Gbandi and Amissah (2014) noted that the contribution of SMEs to the Nigeria GDP has remained well below 5\%. Also, the Central Bank of Nigeria (2018) has noted that there has been gross under performance of the SMEs' sub-sector and this has undermined its contribution to the economic growth and development in Nigeria.

Measuring SMEs' performances has attracted attention from several scholars and has generated lots of arguments as there have been no universally recognized measures of this concept. Nevertheless, SMEs' performances have been measured using the subjective and objective data (Dess and Robinson 1984; Croteau and Bergeron 2001). The subjective data measurement is based upon the perception of the SMEs' owners/managers while the objective data measurement is based on the financial data of the SMEs, usually captured by the organizations' return on investment, return on expenditures, return on capital expenditure, net present value, among others. In this study, SMEs' performance was captured using the profit after tax of the organization through 5 years. With the growing interest on SMEs and their low level of performance especially in Nigeria, it is important to understand the contributory factors that influence their performance.

From a general perspective, Hashim (2000), Jamil and Mohamed (2011), Hakimpoor et al. (2011), and Kutllovci et al. (2012) stated that the lack of capital and credit facilities; shortage of skilled workers and raw materials; inadequate infrastructure; lack of managerial, marketing, and technical expertise; limited applications of new technology; fast changing technology; competition; and socio-cultural, economic, and international factors have significant effect on the success and failure of SMEs. Also, business registration, business size, nature of business, and sources of capital are major factors determining SMEs' performance in Nigeria (Bowale and Ilesanmi 2014). The Central Bank of Nigeria (2018) noted that unfriendly business environment, poor funding, low managerial skills, and lack of access to and use of modern technology are also major factors influencing the performance of SMEs in Nigeria. Of importance to this study is the poor use of information and communications technology (ICT). Examples of ICTs are Internet, social networking sites, e-mail, the mobile phone, CD-ROM, DVD, handheld personal devices, and an ever-growing array of new technological inventions (Omiunu 2017).

The importance of information and communications technologies (ICTs) to development which cut across personal, sectoral, and national spaces cannot be over-emphasized. In the education system, ICTs have been known to aid educational activities and performance of learners. Studies such as Ajiferuke and Olatokun (2009), Ifijeh et al. (2015), and Omiunu (2017) noted that ICTs are powerful tools that can improve the elasticity of quality and performance of SMEs. Also, studies such as Croteau and Bergeron (2001), Laudon et al. (2006), Jamil and Mohamed (2011), and Omiunu (2014) have outlined the importance of ICT to SMEs' performances.

Ladokun et al. (2013) noted that ICT has the potential to improve the core business of SMEs in every step of the business process. Also, (Hoque 2015) affirmed that the use of ICT can develop capabilities for managing information, creating intensive resources, enjoying reduced transaction costs, developing capacity for information gathering and dissemination of international scale, and gaining access to rapid flow of information 
among SMEs. In addition, ICT use can bring about effective strategic management, communication and collaboration, customers' access, managerial decision making, and data and knowledge management among SMEs (Sajuyigbe and Alabi 2012). Ladokun et al. (2013) also noted that it helps to provide an effective means of organizational productivity and service delivery. Furthermore, Ashrafi and Murtaza (2008) attested that ICT have positive effect on SMEs' performance in terms of productivity, profitability, market value, and market share.

Despite these benefits accruing to the use of ICT among SMEs, Ajiferuke and Olatokun (2009) noted that few countries like China, India, Brazil, the UK, and the USA are successfully taking advantage of the opportunities ICTs offer and have made significant improvements in their economic achievements especially in their SMEs. In addition, several developing countries, Nigeria inclusive, are beginning to derive some of the potential benefits that ICT provides for development. It is also stated that Nigeria, like most developing countries, is an "information-poor" country where the use of ICTs is still in its infancy. Of which, this is the case in Nigeria's SMEs where ICT adoption by local SMEs is very poor, thus affecting their development and performance and hence limiting their global marketing competition (Ajiferuke and Olatokun 2009). Also, Ladokun et al. (2013) asserted that SMEs in Nigeria are not familiar with the use of various ICT in a way that could enhance their performance. ICT facilitates to enhance performance of SMEs involving the use of information technologies such as computers, hardware, software, database, Internet, and other information systems.

Organisation of Economic Co-operation and Development (OECD) (2017) has noted that digitalization offers new opportunities for SMEs to participate in the global economy, but SMEs in developing countries such as Nigeria are lagging behind in the digital transition and the disruptive effects of this need to be considered and addressed. A major factor that hinders the adoption of ICT and causes the disruptive effects for SMEs' growth and development is literacy in the use of ICT. To fully function in the digital world and information society-which in this study could be synonymous to increase SMEs' development-users (which are SMEs' owners) must possess certain level of ICT literacy (MediaSmarts 2017). In this study, ICT literacy is conceptualized as e-literacy. In the changing information society, the concept of literacy has changed from the traditional platform and view such as in the traditional reading and writing to the electronic platform known as ICT literacy (or rather e-literacy as conceptualized in this study). ICT literacy or e-literacy refers to some sets of literacy in the use of ICT that a user should possess in order for such user to efficiently adopt it for developmental purpose. Husseini and Safa (2009) show that in the information society, e-literacy skill is important and predicts the use of ICT such as for SMEs' growth and development. E-literacy is beyond the technological know-how of ICT, and it includes a wide variety of ethical, social, and reflective practices that are embedded in work, learning, leisure, daily life, and SMEs' activities.

Stork and Schmidt (2009) noted that the absence of necessary skills could marginalize those who can access and afford to use ICT services. To this end, Deen-Swarray 2016 affirmed that users must develop certain skills, such as the ability to understand, use, modify, and create content and services, to fully benefit from using ICTs. From a broader view, e-literacy skills can help individuals develop e-skills, such as the ability to modify content, required to experience the full benefits and make optimal use of ICTs 
(Deen-Swarray 2016). However, Deen-Swarray (2016) affirmed that existing literature on the relationship between e-literacy and use in Africa is insufficient. Stork and Schmidt (2009) stated that users who lack e-literacy are likely to lag behind in their use of ICTs and thus could influence their performance. E-literacy is also known as "multi-literacy", and it is being approached from the continuum of literacy needed in the use of ICT and covers concepts such as media, computer, digital, information, technology, and visual literacy (MediaSmarts 2017). More of this literacy would be explained at the literature review section.

In the meantime, adapting the information technology trilogy model of Croteau and Bergeron (2001), given a type of "business strategy," a question to look at is what type of technology deployment best enhances the performance of firms? Another major variable to consider in this study is business strategy. With respect to this study, the concept of "business strategy" would be used as "business information strategy." While "business strategy" refers to the provision of the ability to understand competitive complexities through a systematic approach with the aim of achieving competitive advantage (Henderson and Venkatraman 1990), "business information strategy" is a link between the "business strategy" and the "information system strategy" (Durodoye 2005).

It implies that business information strategy (BIS) covers information and several information systems required to support primary tasks or the daily activities of the business strategy employed by the SMEs. Both business strategy and business information strategy are important to enhance SMEs' performances. Business information strategy is based on key principles which define the SMEs' attitude towards information and information systems, their use, and their availability. Also, there is a need to develop a fit and alignment between ICT adoption and business information strategy (Durodoye 2005) because such alignment has major advantages to SME performance. Croteau and Bergeron (2001) proposed two strategic possibilities of ICT: the impact and alignment approach. In respect to the impact approach, ICT is being revealed to influence business information strategy which would in turn influence SME performance. In respect to the alignment approach, ICT literacy or e-literacy could also be said to enhance the relationship between the adoption of ICT and business information strategy towards achieving an enhanced performance of women-owned SMEs.

Thus, one can hypothesize that considering the relationship between ICT adoption and performance, e-literacy could serve as a mediating variable between them, and business strategy of SMEs can be affected by ICT adoption and could also have impact on performance of SMEs. With regard this, Pires and Aisbett (2003) affirmed that if a firm adopts ICT-based innovations without a clear understanding (which in this study could be conceptualized as e-literacy) of the scope and implications of that adoption, then not enough attention may be paid to realigning business strategy which in this study is conceptualized as business information strategy. Sandada et al. (2014) noted that business strategy, which is reconceptualized to business information strategy in this study due to the metamorphosis of its usage in the information society, affects SMEs' performance. In addition, e-literacy can be used to enhance business information strategy and can further enhance the effect of business strategy on SMEs' performance (Pires and Aisbett 2003; Govender and Pretorius 2015). Furthermore, Mahmood and Hanafi (2012) affirmed that demographic, social change, and innovative ability, which in this study could be 
used as a subset of ICT literacy could affect SMEs' performance in Nigeria. A major demographic characteristics considered in this study is gender.

About 40 to $50 \%$ of SMEs are owned and run by women, and there is evidence of marginalization of women in every sector, including SME (Omiunu 2014). In addition, Watson (2003) noted that gender difference, which is a major demographic characteristic as stated by Mahmood and Hanafi (2012), is a major issue that has been observed to affect performance of SMEs in developing countries such as Nigeria. In addition, women-owned SMEs are generally denied resources such as ICT within the society, and because women could not compete with their male counterparts, they tend to have less access to major resources such as ICT that could enhance their performance (Watson 2003). Therefore, Watson (2003) affirmed that SMEs owned by women under-performed more than those owned by men. Juxtaposing the works of World Intellectual Property Organisation (Omiunu) (2014) and Watson (2003) and those of Croteau and Bergeron (2001), Deen-Swarray (2016), Husseini and Safa (2009), Ladokun et al. (2013), among others, it could be evidenced that women in developing countries such as Nigeria could face the challenge of poor adoption of ICT to enhance their business due to lack of e-literacy. Hence, it seems proper to concentrate on women-owned SMEs in Nigeria and how their level of e-literacy could affect the adoption of ICT with relevant business information and information systems that could be used to enhance major business strategies for a better business performance in Nigeria. To this end, the following hypotheses are used to drive this study and are subjected to test at 0.05 level of significance:

Ho1: There is no significant relationship between ICT adoption and performance of women-owned SMEs in Southwestern, Nigeria.

Ho2: There is no significant relationship between business information strategy and performance of women-owned SMEs in Southwestern, Nigeria.

Ho3: There is no significant relationship between ICT adoption and business information strategy adopted by women-owned SMEs in Southwestern, Nigeria. Ho4: Business information strategy would not have a significant effect on the relationship between ICT adoption and performance of women-owned SMEs in Southwestern, Nigeria.

Ho5: ICT literacy would not have significant effect on relationship between ICT adoption and performance of women-owned SMEs in Southwestern, Nigeria.

Ho6: There is no significant relationship between e-literacy and business information strategy adopted by women-owned SMEs in Southwestern, Nigeria.

\section{Literature review}

The use of information and communications technology (ICT) to enhance development has attracted interest and debates in developmental studies. Research on SMEs has also attracted interest among stakeholders of development including scholars. Thus, the adoption of ICT to enhance SME performance and development is a major area of concentration in economic development of nation. The need for the adoption of innovation that could enhance the performance and development of SMEs was established when one conceptualized the problems faced by SMEs in developing 
countries such as Nigeria. Hashim (2000), Jamil and Mohamed (2011), Hakimpoor et al. (2011), Kutllovci et al. (2012), and Fowler (2017) stated that major problems faced by SMEs in Nigeria are a weakly developed business environment; corruption; complex entry regulations; poor access to finance; inadequate power supply; lack of skilled management manpower; lack of access to new market opportunities; shortage of skilled workers and raw materials; inadequate infrastructure; lack of managerial, marketing, and technical expertise; limited applications of new technology; fast changing technology; high rate of competition; and socio-cultural, economic, and international factors. More importantly, the Central Bank of Nigeria (2018) noted that the poor adoption and low use of modern technology hampers the performance of SMEs in Nigeria. According to Omiunu (2017), examples of ICTs are Internet, social networking sites, e-mail, the mobile phone, CD-ROM, DVD, handheld personal devices, and an ever-growing array of new technological inventions.

Hyvönen et al. (2003) advocated that the utilization of ICT is one of the key areas that modern businesses develop in order to achieve strategic gains and increase performance. To this end, there is a global shift as SMEs around the world are now utilizing ICT not only to cut costs and risks and to improve organizational efficiency, but to provide a better customer service towards enhancing organizational performance. Spanos et al. (2002) and Buhalis (2003) noted that ICTs enhance business relationship and performance because ICT can play a prominent role to create opportunities for SMEs and also combat competitive pressures from competitors.

However, despite the significant elastic benefits of ICT, van Dijk (2005) and Deen-Swarray (2016) affirmed that the effective use of ICT requires e-skills which in this study refer to ICT literacy, or rather e-literacy as conceptualized in this study. E-literacy is the ability to use ICTs such as computer, Internet, and network sources, in a way to achieve particular goals and improve development (which could mean personal, community, sectoral, national) in society. Deen-Swarray (2016) stated that the process of taking advantage of ICT involves being aware of the opportunities presented through devices and knowing how to use the tools which in this study is conceptualized as e-literacy. Deen-Swarray (2016) noted that the definitions of literacy must take on varying dimensions to encompass what it actually means to be literate in today's information age. To this end, MediaSmarts (2017) noted that to be functional in recent digital world and information society, users must possess ICT literacy which is conceptualized as e-literacy. Husseini and Safa (2009) show that in the information society, ICT literacy is important and predicts the use of ICT such as in SMEs as conceptualized in this study.

MediaSmarts (2017) defined ICT literacy or e-literacy as a "multi-literacy" concept that is approached from the continuum of literacy needed to efficiently use ICT, and it covers concepts such as media, technology, information, visual, computer, and digital literacy. Media literacy refers to the ability to access, analyze, evaluate, and produce media through understanding and appreciation of the art, meaning and messaging of various forms of media texts, the impact and influence of mass media and popular culture, and how media texts are constructed and why they are produced. It also includes how they can be used to communicate personal ideas effectively. Technology literacy is seen as the proficiency obtained in the use of technology, and it is most often associated with digital literacy and ranges from basic computer skills to more complex tasks 
like editing a digital film or writing computer code which could be adopted and used in computer programming. Information literacy covers the ability to access information needed and to know how to find it online and how to critically evaluate and apply it.

Visual literacy refers to the ability to understand and produce visual messages, whether through objects, actions, or symbols, and it is essential to both learning and communication in the modern society. Computer literacy is the basic and non-technical knowledge about computers and how to use them and the familiarity and experience with computers, software, and computer systems. It is an understanding of the concept, terminology, and operations that relate to general computer use. It is the essential knowledge needed to function independently with a computer system. Digital literacy refers to the set of competencies required for full participation in a knowledge society and includes knowledge, skills, and behaviors involved in the effective use of digital devices such as smartphones, tablets, laptops, and desktop PCs for purposes of communication, expression, collaboration, and advocacy. The multi-dimensional scope of ICT literacy and its significance to ICT adoption towards enhancing performance is a major focus of this study.

In conclusion, studies on ICT literacy which in this study is referred to as e-literacy on SMEs' performance are few. However, few studies have tried to express and explain their relationship. Digital Innovation for Growth Academy (2014) and Baker and Lomax (2014) have noted that digital literacy which in this study is conceptualized as e-literacy enhances business performance. For SMEs, digital technologies possess the potential to provide significant business opportunities to business growth (Digital Innovation for Growth Academy 2014). However, Parida (2010) and Digital Agenda for Europe: A Europe, 2020, European Commission (2010) cited in Baker and Lomax (2014) have noted that this significant effect on growth and productivity of SME which is to be brought about by digital technologies has been limited due to the lack of literacy or skills in using them. This has made e-literacy germane in the studies of SMEs especially in recent ICT era if they should enjoy the benefits that ICT brings to development. This present study focuses on providing an e-literacy-adoption model for an enhanced performance of women-owned SMEs in Southwestern Nigeria.

\section{Research framework}

The theory used in this study was that of information technology trilogy by Croteau and Bergeron (2001). The theory postulated that, given a type of business strategy, what type of technology deployment best helps firms enhance their performance? The model is presented below in Fig. 1:

Croteau and Bergeron (2001) examined the links among business strategy, technological deployment, and organizational performance. In addition, apart from using business strategy and technological deployment as independent variables, Croteau and Bergeron (2001) also used both as mediating variables, interchangeably and vice versa, which in turn influences organizational performances (as the dependent variable). Tarute and Gatautis (2014) stated that ICT adoption can enhance the productivity growth, organization expansion, efficiency, effectiveness, and competitiveness of SMEs. Also, Tarute and Gatautis (2014) and Tsambou and 


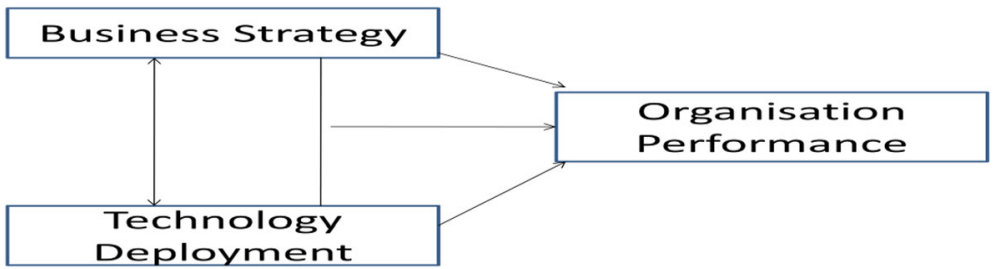

Fig. 1 Information technology trilogy model. Source: Croteau and Bergeron (2001). The information technology trilogy model shows that the elasticity of organizational performance is a function of two major important factors especially in the ICT era, and these are the technology deployed and the business strategy adopted. Also, there is the co-alignment of both the technology deployment and the business strategy adopted by an organization. Croteau and Bergeron (2001) noted that the co-alignment of the technology deployment and the business strategy adopted increases organizational performance than when they are used differently by an organization, hence the need for co-alignment to enhance performance of organization

Kamga (2014) noted that ICT adoption helps increase SMEs' performance. In addition, Janke and Packová (2013), Tarutè and Gatautis (2014), and Mesároš et al. (2016) affirmed that ICT adoption could have significant impact on SMEs' performance. Thus, one could assume that:

Ho1: There is a significant relationship between ICT adoption and performance of women-owned SMEs in Southwestern, Nigeria.

From Sandada et al. (2014), business information strategy can influence SMEs' performance. Also, Mesároš and Mandičák (2017) noted that business intelligence which in this study could be synonymous to and conceptualized as business information strategy does have impact on SMEs' performance. Tsambou and Kamga (2014) affirmed that ICT enhances SMEs' performance when the organization provides innovative support through various acquisition of information systems. Thus, innovative support which in this study could mean business information strategy, as stated by Tsambou and Kamga (2014), has significant impact on SMEs' performance. Also, business information strategy could have significant impact on SMEs' performance as many activities of SMEs which are used for performance criteria such as marketing and sales, logistics and delivery, after-sales service, supply chain management, and other business functions are integrated in an overall e-business strategy (Organisation for Economic Co-Operation and Development (OECDs) 2004). Thus, one could also assume that:

Ho2: There is significant relationship between business information strategy and performance of women-owned SMEs in Southwestern, Nigeria.

In addition, Organisation for Economic Co-Operation and Development (OECDs) (2004) noted that ICT adoption and use has significant impact on e-business strategy which is conceptualized as business information strategy in this study. Also, Donat (2010) and Ghobakhloo et al. (2012) found that ICT adoption has significant impact on business strategy which in this study is conceptualized as business information strategy. To this end, the study assumes that:

Ho3: There is significant relationship between ICT adoption and business information strategy adopted by women-owned SMEs in Southwestern, Nigeria.

Also, Ghobakhloo et al. (2012) noted that ICT is mixed with business information strategy and it has significant effect on the performance of SMEs. Thus, one can assume that: 
Ho4: Business information strategy would have a significant effect on the relationship between ICT adoption and performance of women-owned SMEs in Southwestern, Nigeria.

Also, adapting the information technology trilogy by Croteau and Bergeron (2001) and the ICT literacy of MediaSmarts (2017) which has been re-conceptualized as e-literacy in this study and covers media, computer, digital, information, technology, and visual literacy, Husseini and Safa (2009) noted that in the present information society, ICT literacy affects the adoption of ICT and, in extension, SMEs' growth and development. Also, Stork and Schmidt (2009) had noted that the absence of literacy skills could lead to digital divide, thus affecting SMEs' growth and development. To this end, it could be assumed that:

Ho5: ICT literacy would have significant effect on relationship between ICT adoption and performance of women-owned SMEs in Southwestern, Nigeria.

Also, Organisation for Economic Co-Operation and Development (OECDs) (2004) noted that the level of ability to use the Internet which is a part of ICT can influence business strategy which is conceptualized as business information strategy in this study. Furthermore, Pires and Aisbett (2003) and Govender and Pretorius (2015) had noted that e-literacy can be used to enhance business information strategy on SMEs' performance. Thus, one can state that:

Ho6: There is no significant relationship between e-literacy and business information strategy adopted by women-owned SMEs in Southwestern, Nigeria.

With regard the six hypotheses, the proposed e-literacy-adoption model for enhanced SMEs' performance for developing countries such as Nigeria is presented in Fig. 2.

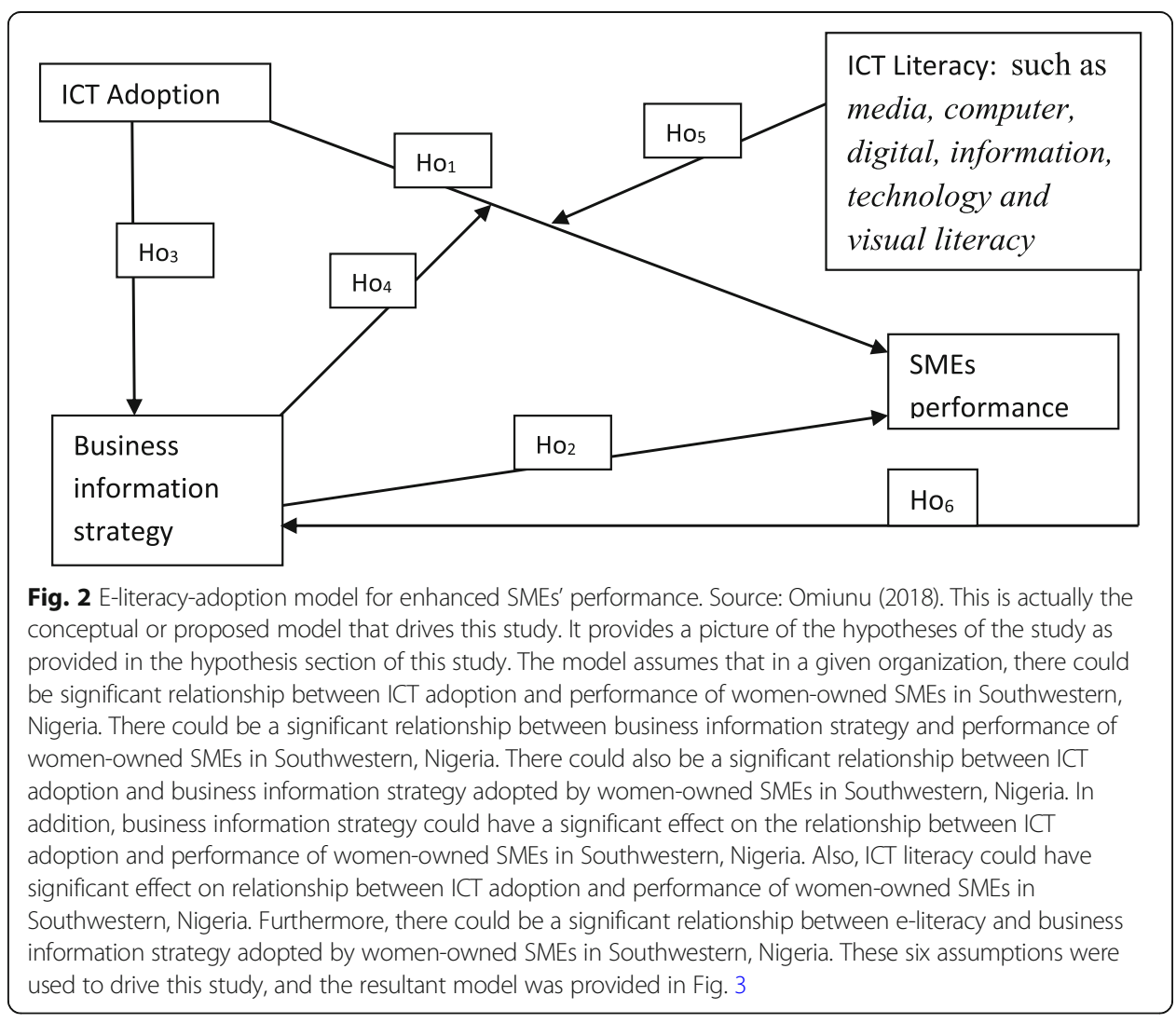


The e-literacy-adoption model for SMEs' performance opined that although ICT adoption can influence SMEs' performance, however, the elasticity of this effect could be affected by e-literacy level of the SMEs' owners. In addition, ICT adoption can influence business information strategy and thus women-owned SMEs' performance.

\section{Research methodology}

The study adopted the correlational survey research design. This type of research design gives room for using a selected sample size from a population of interest for a research purpose and for using the result obtained to draw inference on the population of study. Also, the correlational aspect of the study seeks to establish a relationship between or among variables of interest in this study as provided by the hypotheses of the study. The population of this study comprised SMEs that are women-owned in Oyo State, Southwestern, Nigeria. Oyo State is located in the Southwestern region of Nigeria, and it is divided into three senatorial districts: Oyo north, Oyo central, and Oyo south (Citt Population 2017). A multi-stage sampling was employed in this study. Oyo State has 33 local government areas, and these local government areas (LGAs) were grouped into the three senatorial districts (strata). At the first stage, a stratified sampling technique was employed to group the local government areas based on the senatorial districts in Oyo State. Table 1 shows the senatorial districts and their local governments.

The second stage involved the selection of two local government areas from each stratum (senatorial district) through a simple random sampling. The third stage involved the use of convenience sampling method to select 40 women-owned SMEs from each local government area giving a total of 240 women-owned SMEs (respondents) (Table 1). The major instrument used for data collection was the questionnaire and was designed to ensure that information and data obtained were relevant to the objectives and research questions of the study. The questionnaire was divided into five sections, namely, demographic variables, SMEs' performance, business information strategy, ICT adoption, and ICT literacy.

To determine the psychometric properties of the instrument, it was subjected to validity and reliability. For the validity, the content and construct validity was done to ensure that the instrument captured the necessary content and variables of the study as presented in the hypotheses of the study. With regard the reliability of the instrument,

Table 1 Senatorial districts and their local governments

\begin{tabular}{cllll}
\hline Senatorial districts & LGA & LGA selected & Sample size \\
\hline 1 Oyo North & $\begin{array}{l}\text { Saki West, Saki East, Atisbo, Irepo, Olorunsogo, Kajola, } \\
\text { Iwajowa, Ogbomoso North, Ogbomoso South, Iseyin, } \\
\text { Oorelope, Oriire, and Itesiwaju }\end{array}$ & $\begin{array}{l}\text { Iseyin and Ogbomoso } \\
\text { South }\end{array}$ & 80 \\
3 Oyo Central & $\begin{array}{l}\text { Afijio, Akinyele, Egbeda, Ogo-Oluwa, Surulere, Lagelu, } \\
\text { Oluyole, Ona-Ara, Oyo East, Oyo West, and Atiba }\end{array}$ & Akinyele and Oluyole & 80 \\
& $\begin{array}{l}\text { Ibadan North, Ibadan North East, Ibadan North West, } \\
\text { Ibadan South East, Ibadan South West, Ibarapa Central, } \\
\text { Ibarapa East, Ibarapa North, and Ido }\end{array}$ & Ibadan North East & \\
Total & 33 & 6 & 240 \\
\hline
\end{tabular}

The senatorial districts and their local governments in Oyo State selected in this study. There are 33 local governments in Oyo State, Southwestern, Nigeria 
a pre-test of the instruments and the major constructs of the instruments were carried out among 30 SMEs which are not part of those selected for the main study. The reliability test which included the whole items in the questionnaire except the demographic characteristics gave a reliability result of 0.84 ; the constructs test gave a reliability result of 0.87 for business information strategy, 0.75 for ICT adoption, and 0.71 for ICT literacy. During the data collection, two hundred and fifty (250) copies of a questionnaire were distributed (to cater for error and waste) from which 236 were retrieved giving a $94.4 \%$ response rate. Data collected with the questionnaires were analyzed quantitatively using the correlation analysis at 0.05 level of significance, and inference was made from the analysis to the population of study.

\section{Results}

The result of the study shows that $76 \%$ of the respondents were married: of these, approximately $12 \%$ of the women-owned SMEs belonged to the other sectors, approximately $4 \%$ belonged to the education sector, approximately $3 \%$ belonged to telecom sector, $2.0 \%$ belonged to the consultancy sector, approximately $2 \%$ belonged to the health sector, and only $1 \%$ belonged to the construction sector; approximately $23 \%$ of the women-owned SMEs were single. Also, approximately $32 \%$ of the respondents were between the age brackets 36 and 45 years, approximately $24 \%$ were between the age brackets of 26 and 35 years, approximately 19\% were between the age brackets of 46 and 55 years, approximately $16 \%$ were below 25 years, and only approximately $10 \%$ were above 55 years. Also, approximately $40 \%$ had tertiary education, $31 \%$ had secondary education, and approximately $26 \%$ had primary education. In addition, approximately $47 \%$ had above 10 years' level of experience, approximately $27 \%$ had level of experience between the brackets 6 and 10 years, and only approximately $26 \%$ had level of experience between the brackets 1 and 5 years.

Also, the correlation analysis to the various hypotheses is presented below:

Ho1: There is no significant relationship between ICT adoption and performance of women-owned SMEs in Southwestern, Nigeria.

The correlation analysis for hypothesis 1 is presented in Table 2.

The result in Table 2 shows that ICT adoption does not have significant relationship with performance of women-owned SME in Nigeria $(p>0.05)$; thus, hypothesis 1 was not rejected. This implies that there is no significant relationship between ICT adoption and performance of women-owned SMEs in Southwestern, Nigeria.

Ho2: There is no significant relationship between business information strategy and performance of women-owned SMEs in Southwestern, Nigeria.

Table 2 Correlation analysis of hypothesis 1

\begin{tabular}{llllll}
\hline Variables & Mean & Std. deviation & Correlations & \\
\cline { 4 - 6 } & & & & ICT adoption & Performance of SME \\
\hline ICT adoption & 22.455 & 13.786 & Pearson correlation & 1 & .032 \\
& & & Sig. (2-tailed) & & .647 \\
Performance of SME & 101.844 & \multirow{2}{*}{18.953} & Pearson correlation & .032 & 1 \\
& & & Sig. (2-tailed) & .647 & \\
& & & $N$ & 209 & 218 \\
\hline
\end{tabular}


The correlation analysis for hypothesis 2 is presented in Table 3.

The result in Table 3 shows that there is a significant relationship between business information strategy (BIS) and performance of women-owned SMEs in Southwestern, Nigeria $(p<0.05)$; thus, hypothesis 2 was rejected. This implies that there is a significant relationship between business information strategy and performance of women-owned SMEs in Southwestern, Nigeria. In addition, the strength or relationship between BIS and performance of women-owned SMEs was small (only 3\%).

Ho3: There is no significant relationship between ICT adoption and business information strategy adopted by women-owned SMEs in Southwestern, Nigeria.

The correlation analysis for hypothesis 3 is presented in Table 4.

The result in Table 4 shows that there is no significant relationship between ICT adoption and business information strategy adopted by women-owned SMEs in Southwestern, Nigeria $(p>0.05)$; thus, hypothesis 3 is not rejected. This implies that there is no significant relationship between ICT adoption and business information strategy adopted by women-owned SMEs in Southwestern, Nigeria.

Ho4: Business information strategy would not have a significant effect on the relationship between ICT adoption and performance of women-owned SMEs in Southwestern, Nigeria.

The correlation analysis for hypothesis 4 is presented in Table 5 .

The result in Table 5 shows that business information strategy does not have a significant effect on the relationship between ICT adoption and performance of women-owned SMEs in Southwestern, Nigeria $(p>0.05)$; thus, hypothesis 4 was not rejected. This implies that business information strategy does not have a significant effect on the relationship between ICT adoption and performance of women-owned SMEs in Southwestern, Nigeria.

Ho5: ICT literacy would not have a significant effect on relationship between ICT adoption and performance of women-owned SMEs in Southwestern, Nigeria.

The correlation analysis for hypothesis 5 is presented in Table 6 .

The result in Table 6 shows that e-literacy has a partial significant impact on the relationship between ICT adoption and performance of women-owned SMEs in Southwestern, Nigeria $(p<0.05)$; thus, hypothesis 5 was rejected. This implies that e-literacy has a significant impact on the relationship between ICT adoption and performance of women-owned SMEs in Southwestern, Nigeria. In addition, digital literacy has the highest mean (69.5776) which makes it to likely be the highest literacy. Information and visual literacy have the lowest means (24.149 respectively), which makes them to

Table 3 Correlation analysis for hypothesis 2

\begin{tabular}{|c|c|c|c|c|c|}
\hline & \multirow[t]{2}{*}{ Mean } & \multirow[t]{2}{*}{ Std. Deviation } & \multicolumn{3}{|l|}{ Correlations } \\
\hline & & & & $\begin{array}{l}\text { Business Information } \\
\text { Strategy }\end{array}$ & $\begin{array}{l}\text { Performance } \\
\text { of SME }\end{array}$ \\
\hline \multirow{3}{*}{$\begin{array}{l}\text { Business information } \\
\text { strategy }\end{array}$} & \multirow[t]{3}{*}{14.5965} & \multirow[t]{3}{*}{4.23998} & Pearson correlation & 1 & $.158^{*}$ \\
\hline & & & Sig. (2-tailed) & & .022 \\
\hline & & & $N$ & 228 & 210 \\
\hline \multirow[t]{3}{*}{ Performance of SME } & \multirow[t]{3}{*}{101.8440} & \multirow[t]{3}{*}{18.95309} & Pearson correlation & $.158^{*}$ & 1 \\
\hline & & & Sig. (2-tailed) & .022 & \\
\hline & & & $N$ & 210 & 218 \\
\hline
\end{tabular}

*Correlation is significant at the 0.05 level (2-tailed) 
Table 4 Correlation analysis for hypothesis 3

\begin{tabular}{llllll}
\hline Variables & Mean & Std. deviation & Correlations & \\
\cline { 3 - 5 } & & & & ICT adoption & $\begin{array}{l}\text { Business information } \\
\text { strategy }\end{array}$ \\
\hline ICT adoption & 22.4550 & 13.78619 & Pearson correlation & 1 & .047 \\
& & & Sig. (2-tailed) & & .496 \\
& & & $N$ & 222 & 214 \\
Business information & 14.5965 & 4.23998 & Pearson correlation & .047 & 1 \\
strategy & & & Sig. (2-tailed) & .496 & \\
& & & $N$ & 214 & 228 \\
\hline
\end{tabular}

probably be the least literacy that contribute to the relationship between ICT adoption and performance of women-owned SMEs.

Ho6: There is no significant relationship between e-literacy and business information strategy adopted by women-owned SMEs in Southwestern, Nigeria.

The correlation analysis for hypothesis 6 is presented in Table 7 .

The result in Table 7 shows that only information literacy and digital literacy were found to be statistically significant $(p<0.05)$; other literacy were not significant $(p>$ $0.05)$. In addition, when brought together, ICT literacy does not have significant relationship with business information strategy $(p>0.05)$. Thus, this implies that only information literacy and digital literacy are the significant literacy to business information strategy of women-owned SMEs.

\section{Discussions of findings}

The findings of this study revealed that ICT adoption does not have significant relationship with performance of women-owned SME in Nigeria. This contrast the works of Croteau and Bergeron (2001), Hoque (2015), Laudon et al. (2006), Ashrafi and Murtaza (2008), Ajiferuke and Olatokun (2009), Jamil and Mohamed (2011), Sajuyigbe and Alabi (2012), Janke and Packová (2013), Ladokun et al. (2013), Tarutė and Gatautis (2014), Tsambou and Kamga (2014), Ifijeh et al. (2015), Mesároš et al. (2016), and Omiunu (2017) that ICTs can improve the quality and performance of SMEs. The findings of this study support the work of Ajiferuke and Olatokun (2009) that Nigeria, like most developing countries, is an "information-poor" country where the adoption and use of ICTs is still in its infancy, thus affecting performance of SMEs in Nigeria, and differs

Table 5 Correlation analysis for hypothesis four

\begin{tabular}{|c|c|c|c|c|c|c|}
\hline \multirow[t]{2}{*}{ Control variables } & \multirow[t]{2}{*}{ Mean } & \multirow[t]{2}{*}{ Std. deviation } & \multicolumn{4}{|l|}{ Correlations } \\
\hline & & & & & ICT adoption & $\begin{array}{l}\text { Performance } \\
\text { of SME }\end{array}$ \\
\hline \multirow{6}{*}{$\begin{array}{l}\text { Business information } \\
\text { strategy }\end{array}$} & \multirow[t]{6}{*}{14.7164} & \multirow[t]{6}{*}{4.21476} & \multirow[t]{3}{*}{ ICT adoption } & Correlation & 1.000 & .014 \\
\hline & & & & $\begin{array}{l}\text { Significance } \\
\text { (2-tailed) }\end{array}$ & - & .843 \\
\hline & & & & $d f$ & 0 & 198 \\
\hline & & & \multirow{3}{*}{$\begin{array}{l}\text { Performance } \\
\text { of SME }\end{array}$} & Correlation & .014 & 1.000 \\
\hline & & & & $\begin{array}{l}\text { Significance } \\
\text { (2-tailed) }\end{array}$ & .843 & - \\
\hline & & & & $d f$ & 198 & 0 \\
\hline
\end{tabular}


Table 6 Correlation analysis for hypothesis five

\begin{tabular}{|c|c|c|c|c|c|c|}
\hline \multirow{2}{*}{$\begin{array}{l}\text { Control variables } \\
\text { (E-literacy) }\end{array}$} & \multirow[t]{2}{*}{ Means } & \multirow[t]{2}{*}{ Std. dev. } & & \multicolumn{3}{|l|}{ Correlations } \\
\hline & & & & & ICT adoption & $\begin{array}{l}\text { Performance } \\
\text { of SME }\end{array}$ \\
\hline $\begin{array}{l}\text { Information } \\
\text { literacy }\end{array}$ & 24.1491 & 2.93089 & \multirow[t]{4}{*}{ ICT Adoption } & Correlation & 1.000 & .236 \\
\hline $\begin{array}{l}\text { Technology } \\
\text { literacy }\end{array}$ & 28.9503 & 5.47243 & & $\begin{array}{l}\text { Significance } \\
\text { (2-tailed) }\end{array}$ & - & .003 \\
\hline Computer literacy & 29.1615 & 5.39433 & & & & \\
\hline \multirow[t]{2}{*}{ Digital literacy } & 69.5776 & 13.63756 & & $d f$ & 0 & 153 \\
\hline & & & \multirow{4}{*}{$\begin{array}{l}\text { Performance } \\
\text { of SME }\end{array}$} & Correlation & .236 & 1.000 \\
\hline Media literacy & 32.8696 & 5.08691 & & Significance & .003 & - \\
\hline \multirow[t]{2}{*}{ Visual literacy } & 24.1491 & 2.93089 & & & & \\
\hline & & & & $\mathrm{df}$ & 153 & 0 \\
\hline
\end{tabular}

from countries like China, India, Brazil, the UK, and the USA who have successfully taken advantage of the opportunities ICTs offer and have made significant improvements in their economic achievements, most especially in their SMEs. This could hinder the new opportunities for SMEs which ICTs give to development such as SMEs' development which include women-owned SMEs. The findings of this study bolster the

Table 7 Correlation analysis for hypothesis six

\begin{tabular}{|c|c|c|c|c|}
\hline & Mean & Std. deviation & & Business information strategy \\
\hline \multirow[t]{3}{*}{ Business information strategy } & 14.5965 & 4.23998 & Pearson correlation & 1 \\
\hline & & & Sig. (2-tailed) & \\
\hline & & & $N$ & 228 \\
\hline \multirow[t]{3}{*}{ Information literacy } & 23.9358 & 3.08788 & Pearson correlation & $.151^{*}$ \\
\hline & & & Sig. (2-tailed) & .028 \\
\hline & & & $N$ & 211 \\
\hline \multirow[t]{3}{*}{ Technology literacy } & 28.3795 & 5.49878 & Pearson correlation & .020 \\
\hline & & & Sig. (2-tailed) & .775 \\
\hline & & & $N$ & 216 \\
\hline \multirow[t]{3}{*}{ Computer literacy } & 29.0565 & 4.92842 & Pearson correlation & .011 \\
\hline & & & Sig. (2-tailed) & .872 \\
\hline & & & $N$ & 222 \\
\hline \multirow[t]{3}{*}{ Digital literacy } & 22.7432 & 3.75636 & Pearson correlation & $-.142^{*}$ \\
\hline & & & Sig. (2-tailed) & .038 \\
\hline & & & $N$ & 215 \\
\hline \multirow[t]{3}{*}{ Media literacy } & 68.9333 & 12.85913 & Pearson correlation & .123 \\
\hline & & & Sig. (2-tailed) & .070 \\
\hline & & & $N$ & 217 \\
\hline \multirow[t]{3}{*}{ Visual literacy } & 32.3981 & 5.36039 & Pearson correlation & .052 \\
\hline & & & Sig. (2-tailed) & .454 \\
\hline & & & $N$ & 208 \\
\hline \multirow[t]{3}{*}{ ICT literacy } & 207.4971 & 20.11005 & Pearson correlation & .103 \\
\hline & & & Sig. (2-tailed) & .186 \\
\hline & & & $N$ & 167 \\
\hline
\end{tabular}


work of and Ladokun et al. (2013) that SMEs in Nigeria are not familiar with the use of various ICTs in a way that could enhance their performance.

In addition, there is a significant relationship between business information strategy and performance of women-owned SMEs in Southwestern, Nigeria. This supports the findings of Pires and Aisbett (2003), Organisation for Economic Co-Operation and Development (OECDs) (2004), Tsambou and Kamga (2014), and Govender and Pretorius (2015) that business information strategy does enhance SMEs' performance. Also, the findings buttressed the work of Sandada et al. (2014) that business information strategy affects SMEs' performance. In addition, the findings of this study support the works of Mesároš and Mandičák (2017) that business intelligence which in this study is conceptualized as business information strategy does have impact on SMEs' performance.

Also, there is no significant relationship between ICT adoption and business information strategy adopted by women-owned SMEs in Southwestern, Nigeria. The findings contrast the work of Durodoye (2005) that there could be a link between ICT adoption and business information strategy. Also, the findings of this study contrast that of Pires and Aisbett (2003) who affirmed that ICT adoption can affect business strategy which in this study is conceptualized as business information strategy. The findings also contrast the works of Organisation for Economic Co-Operation and Development (OECDs) (2004), Donat (2010), and Ghobakhloo et al. (2012) that ICT adoption and use has significant impact on e-business strategy which is conceptualized as business information strategy. Furthermore, business information strategy does not have a significant effect on the relationship between ICT adoption and performance of women-owned SMEs in Southwestern, Nigeria. This supports the findings of Pires and Aisbett (2003) that a firm business information strategy can have a significant effect on the relationship between ICT adoption and performance of SMEs, which are women-owned SMEs with regard this study. Also, the findings of this study contrasts the work of Ghobakhloo et al. (2012) who noted that ICT needs to be mixed with business information strategy before it can have significant impact on the performance of SMEs.

Also, ICT literacy has a significant effect on the relationship between ICT adoption and performance of women-owned SMEs in Southwestern, Nigeria, with digital literacy having the highest effect and information and visual literacy having the least effect. The findings of this study bolster the work of MediaSmarts (2017) that to fully enjoy the benefits which ICT brings in the information society, SMEs' owners must possess certain level of ICT literacy. It also supports the work of Husseini and Safa (2009) that ICT literacy and skill are important to the use of ICT for growth and development of business, which include SMEs. Also, the finding bolstered the work of Stork and Schmidt (2009) that users who lack ICT literacy may eventually use ICT inefficiently and/or it may affect their performance negatively, women-owned SMEs not exclusive. Moreover, only information literacy and digital literacy are found to be statistically significant, while other literacy were not. In addition, when brought together, ICT literacy does not have significant relationship with business information strategy. This supports the findings of Pires and Aisbett (2003), Organisation for Economic Co-Operation and Development (OECDs) (2004), and Govender and Pretorius (2015) that the level of ability to use the Internet which is a part of ICT can influence business strategy, which is conceptualized as business information strategy in this study. 


\section{Conclusion and recommendations}

In conclusion, ICT literacy could be observed to be one of the major factors that influence the effective utilization of ICT to enhance business information strategy and performance of women-owned SME in Nigeria. To this end, the significance of ICT literacy to business information strategy in the adoption of ICT for effective performance among women-owned SMEs in Nigeria cannot be over-emphasized. The resultant model of this study is thus presented in Fig. 3.

Furthermore, the study recommends that:

i. ICT trainings and workshops should be provided for women-owned SMEs by governments and other stakeholders who may deem it fit to enhance SMEs' performance in developing countries such as Nigeria. This could enhance ICT skills and literacy which could have a long-term effect on women-owned SMEs' performance.

ii. Also, more grants should be introduced and sponsored by various NGOs who are committed to providing grants for business development in developing countries, and these grants should be directed at the training of women-owned SMEs in developing countries, Nigeria inclusive. This could enhance ICT skills and literacy which could have a long-term effect on women-owned SMEs' performance.

iii. Also, governments and the various NGOs can donate necessary ICT materials that could enhance women-owned SMEs' performance and provide training in their use.

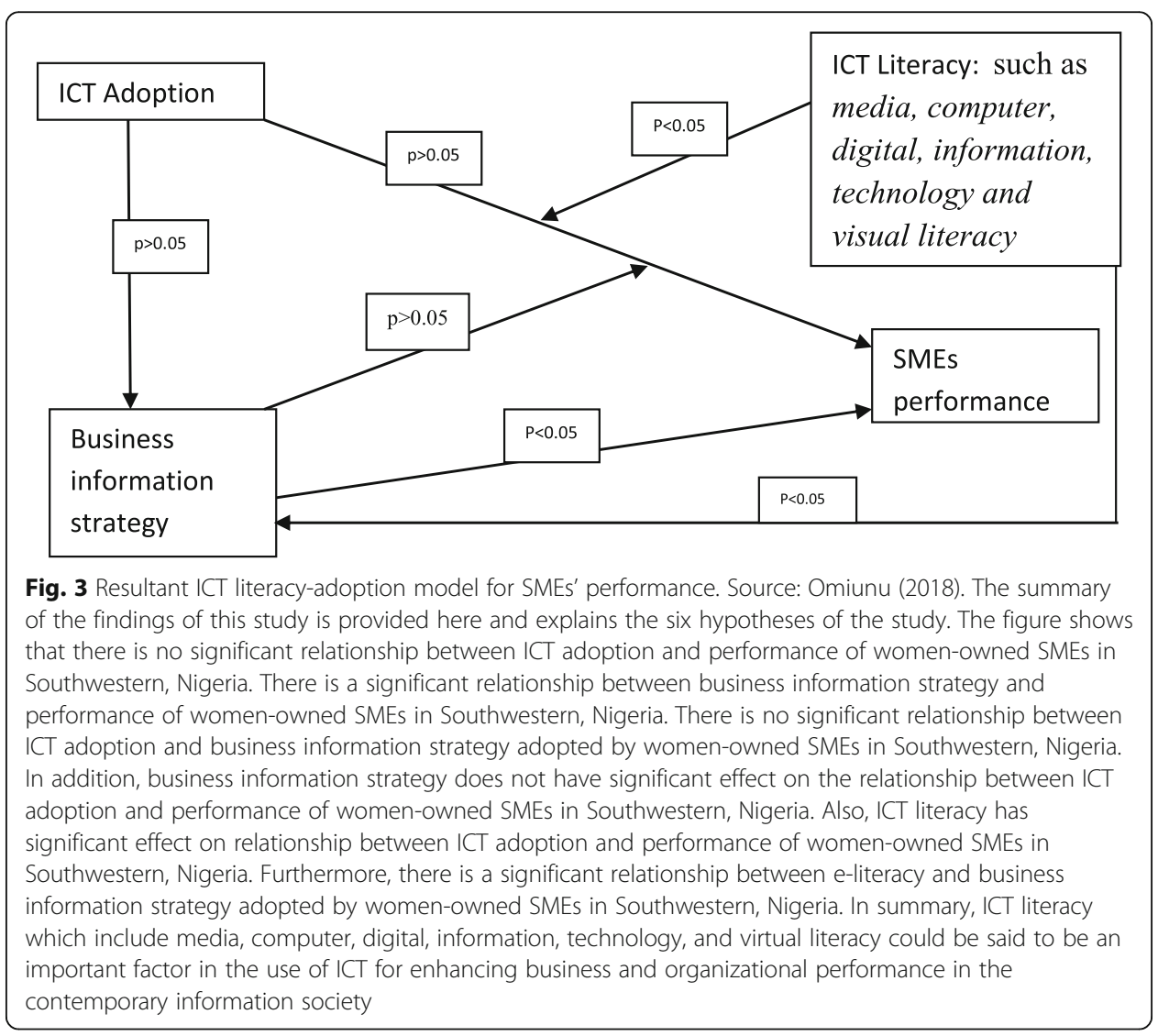


iv. Also, the education ministry could provide a short and distance learning online course in the use of ICT to enhance ICT literacy and also to enhance ICT use in business development. This training could be introduced especially for women business owners. Also, various grants should be provided to aid this course towards enhancing ICT literacy and performance of women-owned SMEs in developing countries such as Nigeria.

v. Also, women-owned businesses should be taught how ICT could be used to enhance business information strategy towards enhancing their performance.

\section{Abbreviations}

ALGON: Association of Local Government of Nigeria-Oyo State; e-literacy: Electronic literacy; ICT: Information and Communications Technology; NGOs: Non-government organizations; OECD: Organisation for Economic Co-Operation and Development; PCs: Personal computers; SMEs: Small and medium enterprises

\section{Acknowledgements}

I would like to appreciate the women-owned SMEs for providing the necessary data for this study and also for believing that this study would be used for research purpose only.

\section{Funding}

Funding for this study was personally provided.

\section{Availability of data and materials}

The author is willing to provide and make the data and material used for this study available at request. However, the names of the SMEs would be withhold due to ethical consideration adopted in this study and during the process of this study. This is because SMEs in general in Nigeria are always afraid to provide necessary information to researchers and any other groups because they are skeptical of the fact that the government may use such information they provided to exploit them as they obtain no benefits from the governments.

Author's contribution

Since I am the sole author, the study was $100 \%$ done by me. The author read and approved the final manuscript.

\section{Competing interests}

The author declares that he has no competing interests.

\section{Publisher's Note}

Springer Nature remains neutral with regard to jurisdictional claims in published maps and institutional affiliations.

Received: 9 May 2018 Accepted: 16 January 2019

Published online: 12 February 2019

\section{References}

Ajiferuke, I., \& Olatokun, W. (2009). Sectoral analysis of ICT use in Nigeria. In Encyclopedia of information science and technology (2nd ed., pp. 3364-3368). USA: Mehdi Khosrow-Pour, Information Resources Management Association.

Ashrafi, R., \& Murtaza, M. (2008). Use and impact of ICT on SMEs in Oman. Electronic Journal of Information Systems Evaluation, $11(3), 125-138$.

Ata A. (2018), The role of SMEs in Asia's economic growth, international finance corporation, World Bank Group 2018. Retrieved from http://www.smefinanceforum.org/post/the-role-of-smes-in-asias-economic-growth on 12th.

Baker G., Lomax S. (2014), Digital capabilities in SMEs: evidence review and re-survey of 2014 small business survey respondents. A report by BMG research and Durham University, BIS research paper number 247, https://assets.publishing. service.gov.uk/government/uploads/system/uploads/attachment_data/file/457750/BIS-15-509-digital-capabilities-in-SMEsevidence-review-and-re-survey-of-2014-small-business-survey-respondents.pdf.

Bowale, E. K., \& Ilesanmi, A. (2014). Determinants of factors influencing capacity of small and medium enterprises (SMEs) in employment creation in Lagos State, Nigeria. International Journal of Financial Research, 5(2) Retrieved from http:// covenantuniversity.edu.ng/Profiles/Bowale-Ebenezer/Determinants-of-Factors-Influencing-Capacity-of-Small-and-MediumEnterprises-SMEs-in-Employment-Creation-in-Lagos-State-Nigeria on 12th January, 2018.

Buhalis, D. (2003). eAirlines: Strategic and tactical use of ICTs in the airline industry. Information and Management, 41, 805-825 https://doi.org/10.1016/j.im.2003.08.015.

Central Bank of Nigeria (2018), SME finance, central Bank of Nigeria, Retrieved from https://www.cbn.gov.ng/devfin/ smefinance.asp on 12th January, 2018.

Citt Population. (2017) Oyo (State, Nigeria) - Population Statistics, Charts, Map and Location. https://www.citypopulation.de/ php/nigeria-admin.php?adm1id=NGA031.

Croteau, A., \& Bergeron, F. (2001). An information technology triology: business strategy, technological deployment and organisational performance. Journal of Strategic Information Systems, 10(2001), 77-99 Elsevier.

Deen-Swarray, M. (2016). Toward digital inclusion: understanding the literacy effect on adoption and use of mobile phones and the Internet in Africa. Information Technologies \& International Development [Special Issue], 12(2), 29-45 Retrieved from https://researchictafrica.net/publications/Conference_Publications/2016_Deen-Swarray_Toward_Digital_Inclusion_-_ 
Understanding_the_Literacy_Effect_on_Adoption_and_Use_of_Mobile_Phones_and_the_Internet_in_Africa_ITID_ CPRsouth_ED.pdf on 12th January, 2018.

Dess, G. G., \& Robinson, R. B. (1984). Measuring organisational performance in the absence of objective measures: the case of the privately-held firm and conglomerate business unit. Strategic Management Journal, 5, 265-273.

Digital Innovation for Growth Academy (2014), Going digital in the small firm - is it all about technology!!! http://www. thewomensorganisation.org.uk/downloads/file/Going_Digital_in_the_Small_Firm_Is_it_all_about_technology.pdf.

Donat, B. (2010). Impact of technology on the business strategy performance relationship in building core competence in Uganda small medium enterprises (SME's) (Proceedings of the 7th International Conference on Innovation \& Management) (pp. 39-43) Retrieved from http://www.pucsp.br/icim/ingles/downloads/papers_2010/part_1/ Impact\%20of\%20Technology\%20on\%20the\%20Business\%20Strategy\%20Performance.pdf on 12th January, 2018.

Durodoye, K. K. (2005). Strategic planning of Information Systems: Research Concepts and Framework, in Information Science concepts, models and application, Africa Regional Centre for Information science series, Volume 1, Edited by Tiamiyu M. A. Africa Regional Centre for Information science, University of Ibadan, Ibadan, Nigeria.

Fowler J.F. (2017). Sierra Leone business: SMES SECTOR: a key driver to Sierra leone's economic growth and prosperity, Awoko newspaper, Retrieved from http://awoko.org/2017/05/08/sierra-leone-business-smes-sector-a-key-driver-to-sierra-leoneseconomic-growth-and-prosperity/ on 12th January, 2018.

Gbandi E.C. and Amissah G. (2014). Financing options for small and medium enterprises (SMES) in Nigeria, European Scientific Journal 10(11), 327-340, Retrieved from http://citeseerx.ist.psu.edu/viewdoc/download?doi=10.1.1.824.4408\&rep=rep1\&type=pdf on 12th January, 2018.

Ghobakhloo, M., Hong, T. S., Sabouri, M. S., \& Zulkifli, N. (2012). Strategies for successful information technology adoption in small and medium-sized enterprises. Information, 3, 36-67. https://doi.org/10.3390/info3010036.

Govender, N. M., \& Pretorius, M. (2015). A critical analysis of information and communications technology adoption: the strategy-as-practice perspective. Acta Commercii, 15(1) Art. \#229, 13 pages. https://doi.org/10.4102/ac.v15i1.229.

Hakimpoor, H., Tat, H. H., \& Khairil, A. A. (2011). Strategic marketing planning (SMP) and SMEs' performance: the moderating effects of structural dimensions of marketing networks. In 2nd International Conference on Business and Economic Research (2nd ICBER 2011) Proceeding 1013-1025.

Hashim, M. K. (2000). SMEs in Malaysia: Past, present and future. Malaysian Management Review 35(1), 22-30.

Henderson J., Venkatraman N. (1990) Strategic Alignment: A model For Organizational Transformation Via Information Technology, Working Paper 3223-90, Sloan School of Management, Massachusetts Institute of Technology.

Hoque R., Saif A.N.M., AlBar A.M., Bao Y. (2015). Adoption of information and communication technology for development: A case study of small and medium enterprises in Bangladesh, Information Development, 32 (4), 986-1000. https://doi.org/ $10.1177 / 0266666915578202$.

Husseini, M., \& Safa, L. (2009). Factors affecting the use of information and communication technologies (ICTs) by Iranian agricultural faculty members. World Applied Sciences Journal, 6(8), 1123-1127 Influencing Factors, Library Philosophy and Practice 2011.4-6.

Hyvönen, T., Järvinen, J., \& Pellinen, J. (2003). ICT and accounting in the strategy process. Frontiers of E-Business Research, 230249 Retrieved from https://www.researchgate.net/publication/229002582_ICT_AND_ACCOUNTING_IN_THE_STRATEGY_ PROCESS on 12th January, 2018.

Ifijeh, G., Michael-Onuoha, H., Ilogho, J., \& Osinulu, I. (2015). Emergence of hi-tech examination malpractices in Nigeria: issues and implications. International Journal of Education and Research, 3(3), 113-122 Retrieved from http://eprints. covenantuniversity.edu.ng/5180/1/Happiness\%202.pdf on 28th January, 2019.

Jamil, C. M., \& Mohamed, R. (2011). Performance measurement system (PMS) in small medium enterprises (SMES): a practical modified framework. World Journal of Social Sciences, 1(3), 200-212.

Janke, F., \& Packová, M. (2013). Impact of ICT investments on performance of companies in transaction economics: evidence from Czechrepublic, Hungary and Slovakia. Quality innovation prosperity, 17, 9-21.

Kutllovci E., Shala V., Troni B., (2012), Business strategy, the key determinants of SME growth in Kosovo, Venet Shala et. al., International Journal of Advances in Management and Economics, 1(3), 42-46.

Ladokun, I. O., Osunwole, O. O., \& Olaoye, B. O. (2013). Information and communication technology in small and medium enterprises: factors affecting the adoption and use of ICT in Nigeria. International Journal of Academic Research in Economics and Management Sciences, 2(6) https://doi.org/10.6007/IJAREMS/v2-i6/443.

Laudon K., Laudon J., and Dass R., (2006). Management Information System, Prentice Hall, Azimuth Interactive Inc. Upper Saddle River, New Jersey

Mahmood R. and Hanafi N. (2013). Entrepreneurial Orientation and Business Performance of Women-Owned Small and Medium Enterprises in Malaysia: Competitive Advantage as a Mediator. International Journal of Business and Social Science, 4(1), 82-90. https://pdfs.semanticscholar.org/4457/3aa1d7f02ae16cd51e1e809927e4411b7e8b.pdf

MediaSmarts (2017). Digital literacy fundamentals, Canada's Centre for Digital and Media Literacy MediaSmarts, Retrieved from http://mediasmarts.ca/digital-media-literacy-fundamentals/digital-literacy-fundamentals on 12th January, 2018.

Mesaros P., Carnicky S., Mandicak T., Habinakova M., Mackova D., and Spisakova M. (2016). Business Intelligence impact on corporate performance in Slovak enterprises - a case study, Journal of Systems Integration, 7(4), 9-18. http://www.sijournal.org/index.php/JSI/article/view/267

Mesároš, P.. \& Mandičák, T. (2017). Impact of ICT on performance of construction companies in Slovakia. IOP Conf. Series: Materials Science and Engineering, 245, 072044. https://doi.org/10.1088/1757-899X/245/7/072044

Ngage Media Services Pvt Ltd (2017), Role of SMEs in economic development of India, Retrieved from http://www. smeventure.com/role-smes-economic-development-india/ on 12th January, 2018.

Omiunu O.G. (2014), ICT deployment, business information strategy and environment information as correlates of performance of women-owned SMEs in Oyo State, Nigeria, An MSc Dissertation submitted to Africa Regional centre for Information Science, University of Ibadan, Ibadan, Nigeria.

Omiunu O. G. (2017). Paradoxical Modeling of the Negative Uses of ICT and their Implications among Secondary School Students in Oyo State, Nigeria, Library Philosophy and Practice (e-journal). 1485. http://digitalcommons.unl.edu/ libphilprac/1485 
Onugu B. A. N., (2005), Small and medium enterprises (SMEs) in Nigeria: problems and prospects, being a dissertation submitted to the St. Clements University in partial fulfilment of the requirements for the award of the degree of doctor of philosophy in management, St. Clements University.

Organisation for Economic Co-Operation and Development (OECDs) (2004), ICT, e-business and SMEs, OECD, Retrieved from https://www.oecd.org/sti/34228733.pdf on 12th January, 2018.

Organisation of Economic Co-operation and Development (OECD) (2017), Enhancing the contributions of SMEs in a global and digitalised economy, Meeting of the OECD Council at Ministerial Level Paris, 7-8 June 2017, Retrieved from https:// www.oecd.org/mcm/documents/C-MIN-2017-8-EN.pdf on 12th January, 2018.

Parida V. (2010), 'Achieving competitiveness through externally oriented capabilities: an empirical study of technology--based small firms", Doctoral Thesis, Lulea University of Technology.

Pires, G. D., \& Aisbett, J. (2003). The relationship between technology adoption and strategy in business-to-business markets the case of e-commerce. Industrial Marketing Management, 32, 291-300 https://pdfs.semanticscholar.org/38e9/ 7f39590f4f4673b1e0758b8367eed94f1463.pdf

Sajuyigbe, A.S \& Alabi, E. (2012). Impact of Information and Communication Technology in Selected Small and Medium Enterprises in Osogbo Metropolis, Nigeria. Jounal of School of Communication and Information Technology, Federal Polytechnic, Offa. 3,(1), 24-35

Sandada, M., Pooeand, D., \& Dhurup, M. (2014). Strategic planning and its relationship with business performance among small and medium enterprises in South Africa. International Business \& Economics Research Journal, 13(3), 659-670.

Spanos, Y. E., Prastacos, G., \& Poulymenakou, A. (2002). The relationship between information and communication technologies adoption and management. Information \& Management, 39(8), 659-675.

Stork, C., \& Schmidt, J. P. (2009). Towards evidence-based ICT policy and regulation: E-skills (Vol. 1, Policy Paper 3). Johannesburg: Research ICT Africa.

Tarutè, A., \& Gatautis, R. (2014). ICT impact on SMEs performance. Procedia - Social and Behavioral Sciences, 110, 1218-1225 Retrieved form https://www.sciencedirect.com/science/article/pii/S1877042813056085 on 12th January, 2018.

Tsambou, A. D., \& Kamga, B. F. (2014). Performance perspectives for small and medium enterprises in Cameroon: innovation and ICTs. Timisoara Journal of Economics and Business, 10(1), 68-87. https://doi.org/10.1515/tjeb-2017-0005.

van Dijk, J. A. G. M. (2005). The deepening divide: inequality in the information society. Thousand Oaks: SAGE Publications.

Watson J., (2003), SME performance: does gender matter? A paper for the Small Enterprise Association of Australia and New Zealand 16th Annual Conference, Ballarat, 28 Sept-1 Oct, 2003.

\section{Submit your manuscript to a SpringerOpen ${ }^{\circ}$ journal and benefit from:}

- Convenient online submission

- Rigorous peer review

- Open access: articles freely available online

- High visibility within the field

- Retaining the copyright to your article

Submit your next manuscript at $\boldsymbol{\nabla}$ springeropen.com 